\title{
Quality characteristics of noodle added with Aster scaber extracts solution and powder
}

\author{
Guy-Min Kim ${ }^{1}$, Hyun-Gi Kim ${ }^{1}$, Ju-Yeon Hong ${ }^{1}$, Young-Jun Choi ${ }^{2}$, Hak-Sik Nam ${ }^{3}$, \\ Seung-Ryeul Shin ${ }^{1 *}$ \\ ${ }^{1}$ Faculty of Herbal Food Cuisine and Nutrition, Daegu Haany University, Gyeongsan 712-715, Korea \\ ${ }^{2}$ Department of Food Nutrition \& Culinary Arts, Daegu Technical University, Daegu 704-724, Korea \\ ${ }^{3}$ Food Institute, Environment Institute Woosol Co., Ltd., Yeongdong 370-701, Korea
}

\section{참취 추출물을 첨가한 국수의 품질 특성}

\author{
김규민 ${ }^{1} \cdot$ 김현기 $^{1} \cdot$ 홍주연 $^{1} \cdot$ 최영준 $^{2} \cdot$ 남학식 $^{3} \cdot$ 신승렬 $^{1 *}$ \\ ${ }^{1}$ 대구한의대학교 한방식품조리영양학부, ${ }^{2}$ 대구공업대학교 호텔외식조리계열, ${ }^{3}$ (주)우솔환경연구원 식품연구원
}

\begin{abstract}
The purpose of this study was to investigate the physicochemical and sensory characteristics of $A$. scaber noodle added with $A$. scaber extract solution or powder. The weight of cooked noodle and noodle added with $A$. scaber extract solution was higher than those of the non-added noodle (control) and dried $A$. scaber powder added noodle. As the amount of $A$. scaber extract solution or powder was increased, the water absorption rate of noodle was decreased. As the amount of $A$. scaber solution or powder was increased, the ' $L$ ' values of noodles were decreased. Since the ' $a$ ' values of all noodles were negative and the ' $b$ ' values of all noodles were positive, the color of all noodles were determined to be yellow green. The $\mathrm{pH}$ of noodles were 5 to 6 in control noodles and noodles with $A$. scaber powder. The $\mathrm{pH}$ of noodle added $A$. scaber extract solution was lower than those of others. As amount of $A$. scaber extract solution or powder was increased, the elasticity of all noodles was decreased. The chewiness of noodles was the highest in noodle added $A$. scaber extract powder. The quality of noodle added $A$. scaber extract solution was the excellent among the all other noodles. This result showed that, the quality characteristics and palatability of noodle added $\boldsymbol{A}$. scaber extract solution or powder was higher than those of control noodle.
\end{abstract}

Key words : Aster scaber, noodle, quality, functionality,

\section{서 론}

참취는 국화과 개미취속에 속하는 여러 해살이 풀로서 향긋하고 쌉쌀한 특징을 가지고 있으며, 지역에 따라 취나 물, 암취, 백운초, 나물취 등으로 불린다. 또한 참취의 뿌리 는 한방에서는 동풍채(東風菜)라 하여 성숙한 참취는 뿌리

*Corresponding author. E-mail : shinsr@dhu.ac.kr Phone : 82-53-819-1428, Fax : 82-53-819-1494

Received 8 April 2015; Revised 16 June 2015; Accepted 18 June 2015.

Copyright (c) The Korean Society of Food Preservation. All rights reserved.
와 함께 약용으로 사용한다. 이들은 진통해독의 효능과 혈 액순환을 촉진시키는 작용을 하고, 근골통, 요통, 두통, 장 염으로 인한 복통 및 인후염, 타박상이나 뱀에 물렸을 때에 이용되어져 왔다(1). 우리들이 일상적으로 섭취하는 식용 식물에 포함되어 있는 비타민, 무기질, 폴리페놀류, 사포닌, 색소 등은 고혈압, 암, 심장병, 당뇨병과 같은 만성적 병의 치유 또는 예방과 관련된 대사산물이 포함되어 있다(2) 참취의 채취는 5 월경 어린잎을 나물 또는 묵나물로 식용 하며, 참취의 어린순은 취나물이라 하며 맛은 대체로 향긋 하고 쌉쌀한 특징을 가지고 있다(3).

국수의 역사는 유럽의 유목민들에 의해 중앙아시아를 거쳐 중국의 한나라 시대에 비단길을 통해서 밀이 도입되어 
정착된 후 밀가루 음식을 총칭하는 말로서 병(餅)이라 하여 다양하고 독자적인 밀 문화를 형성하였으며 지금의 가늘고 긴 형태의 국수는 3 세기 무렵으로 중국의 위나라에서 처음 으로 나타나 다양한 재료와 조리법에 따라 많은 종류의 국수가 발달하였다(4).

국수의 독특한 조직감은 밀이나 곡류의 단백질성분인 글리아딘의 점성과 글루테닌의 탄성이 물과 소금을 혼합하 여 물리적 힘을 가하면 독특한 망상구조에 의해 점탄성의 조직감이 만들어지며 국내 식품분류에 의하면 생면류, 건 면류, 숙면류, 파스타류, 즉석면류 등으로 분류된다(5). 국 수는 밀가루의 글루텐 성분을 이용한 가공식품으로 필수아 미노산인 lysine과 함황아미노산이 부족한 편이므로 건강 에 대한 관심이 높아진 최근에 국수제조 시 대두분말(6), 마늘분말(7), 양파즙(8), 발아현미(9) 등을 첨가하여 국수의 품질 기능성이 증대된다는 연구와 다양한 식재료를 이용한 들깻잎분말국수(10), 자색고구마분말국수(11), 발아약콩가 루국수(12), 진피가루국수(13), 청 량고추 착즙액국수(14) 등 유용성분이 함유되어 있는 면류를 연구 개발하여 다양한 소비자의 기호도를 충족하는 국수들이 시판되고 있다.

특히 최근에는 가공식품과 대치되는 개념인 '자연주의' 를 추구하는 경향이 강하게 나타나고 있으며 그 과정에서 인기를 모으기 시작한 것이 바로 생면이다(15). 고품질에 대한 소비자의 기호도 증가로 건면 중심에서 생면 중심으로 소비추세가 바뀌고 있으며 매출도 꾸준히 매년 늘고 있다 (16). 그리고 최근 식품산업의 급격한 발전과 식품의 소비추 세가 고급화되고 편리화 됨에 따라 냉동, 냉장 등의 저장식 품, 가공식품 및 인스턴트식품 등의 이용이 급격히 증가하 고 있는 가운데 면류 산업은 편리성 및 경제적 이점에 의해 꾸준히 성장하고 있는 사업 중의 하나이다(17).

따라서 본 연구는 참취의 재배 및 생산량의 증대에 따른 품질과 기능성에 대한 평가, 그리고 참취의 부가가치 창출 및 재배 농가의 소득 증대를 위하여 참취를 이용한 가공식 품을 개발하였다. 이에 참취의 착즙액 및 분말을 첨가하여 참취 국수의 제조방법을 개발하고 참취 국수의 이화학적 특성과 조리국수의 관능적 특성을 조사하였다.

\section{재료 및 방법}

\section{재 료}

본 연구의 주재료인 참취(Aster scaber)는 2012년 5월에 경북 영양군 지역에서 직접 채취하였으며, 채취한 참취는 이물질을 제거 및 세척하였다. 참취 착즙액은 채취한 참취 를 녹즙기(ANG 7700, Angel, Seoul, Korea)를 이용하여 착 즙한 후 여과지로 여과한 즙액을 제조하였다. 그리고 참취 의 분말은 상온에서 건조한 참취를 분쇄기(AMS330TS, Shinil, Seoul, Korea)로 80 120 mesh 분쇄하여 제조하였다.
제조된 시료는 일정량으로 분취하여 $-75^{\circ} \mathrm{C}$ 초저온냉동고 에서 보관하면서 사용하였다. 국수 제조를 위한 밀가루(중 력분) 및 부재료인 소금은 대형마트에서 구입하여 사용하 였다.

\section{참취 국수의 재료 배합비 및 국수 제조}

참취 국수의 제조는 Lee 등(18)의 방법을 참고로 하여 수차례 예비 실험한 결과 참취 착즙액과 참취 분말을 각각 $5 \%$ 이상 첨가하였을 경우 색과 반죽에 대한 기호도가 현저 히 감소하여, 착즙액은 $4 \%$, 분말은 $3 \%$ 비율까지만 첨가량 을 결정하여 제조하였으며, 재료배합비는 Table 1 과 같다. 밀가루 $100 \mathrm{~g}$ 에 물은 $45 \%$ 를 넣고, 각 참취 착즙액(참취 착즙액과 증류수 $1: 2,1: 4$ 비율로 착즙기에 각 갈아서 넣고 여과지에 2회 걸러준다)과 참취 분말( $1,3 \%$ 비율)을 넣고 밀가루 중량을 기준으로 $3 \%$ 소금을 녹인 후 각각 첨가하여 참취 국수를 제조하였다. 밀가루 반죽에 참취 착즙액과 분 말을 첨가하지 않은 것을 무첨가군으로 하여 총 5 군으로 국수를 제조하였다.

각 재료를 배합 한 후 5 분간 손으로 반죽한 후, 식품 포장용 위생비닐에 넣어 $4 \pm 1^{\circ} \mathrm{C}$ 냉장고에 1 시간 숙성시킨 후, 국수 제조기(YMC-102, 용마기계, Seoul, Korea)로 롤 간격을 $8 \mathrm{~mm}$ 로 하여 2번 sheeting하고, 형성된 면대를 4 $\mathrm{mm}$ 로 하여 가로, 세로로 각각 2 번 복합하여 다시 sheeting한 후 폭 $1.8 \mathrm{~mm} \times 1.8 \mathrm{~mm}$, 길이 $30 \mathrm{~cm}$ 의 생면을 제조하였고 조리면은 $100^{\circ} \mathrm{C}$ 에서 3 분 동안 삶은 후 흐르는 물에 30 초 동안 세척하여 완성 후 별도의 건조 과정 없이 생면과 조리 면의 상태로 본 실험에 사용하였다.

Table 1. Preparation formula of noodles added Aster scaber extract solution and powder

\begin{tabular}{lccccc}
\hline \multicolumn{1}{c}{ Ingredients } & Control $^{1)}$ & AJ1 & AJ2 & AP1 & AP2 \\
\hline Wheat flour (g) & 100 & 100 & 100 & 99 & 97 \\
$\begin{array}{l}\text { Aster scaber } \text { extract } \\
\text { solution (mL) }\end{array}$ & - & 9 & 15 & - & - \\
Aster scaber powder (g) & - & - & - & 1 & 3 \\
Water (mL) & 45 & 36 & 30 & 45 & 45 \\
Salt (g) & 3 & 3 & 3 & 3 & 3 \\
\hline
\end{tabular}

${ }^{1)}$ Control, noodles not added Aster scaber extract solution and powder; AJ1, noodles added Aster scaber extract solution and water (1:4); AJ2, noodles added Aster scaber extract solution and water (1:2); AP1, noodles added Aster scaber powder of $1 \%$; AP2, noodles added Aster scaber powder of $3 \%$.

\section{조리 국수의 이화학적 특성}

국수의 조리 특성은 Park과 Cho의 방법(19)을 응용하여 참취 착즙액과 분말 첨가 국수의 중량은 생면 $30 \mathrm{~g}$ 을 300 $\mathrm{mL}$ 의 증류수에 넣고 $100^{\circ} \mathrm{C}$ 에서 3 분간 조리한 다음 체에 밭쳐 30 초 동안 찬물에 헹구고 물을 뺀 후 1 분간 방치하여 수분을 제거하여 측정하였다. 
조리 국수의 부피는 중량을 측정한 후 바로 $300 \mathrm{~mL}$ 의 물을 채운 메스실린더에 국수를 넣은 후 증가하는 물의 부피로 측정하였다.

조리 국수의 수분 흡수율은 삶아서 측정한 국수의 중량 에서 생 국수의 중량을 빼고 다시 생 국수의 중량으로 나눈 값에 100 을 곱하여 측정하였다.

Water absorption $(\%)=\frac{\text { 조리 후 생면 중량(W1) - 조리 전 생면 중량(W0) }}{\text { 조리 전 생면 중량(W0) }} \times 100$

조리 국물의 탁도는 삶은 국수를 건져낸 물을 상온에서 냉각한 후 spectrophotometer(Hitachi U-2001, Hitachi, Tokyo, Japan)를 사용하여 $675 \mathrm{~nm}$ 에서 흡광도를 측정하였다.

\section{국수의 수분 정량 및 $\mathrm{pH}$ 측정}

참취 국수 생면의 수분 함량은 적외선 수분 측정기 (Presisa HA-300, Presisa, Frawil, Switzerland)를 이용하여 측정하였으며, $\mathrm{pH}$ 는 국수 생면 $10 \mathrm{~g}$ 에 증류수 $90 \mathrm{~mL}$ 를 첨가하여 마쇄기로 1 분간 마쇄한 후 $\mathrm{pH}$ meter(HM $25 \mathrm{R}$, Tokyo, Japan)를 이용하여 측정하였다.

\section{국수의 색도 측정}

참취 국수 생면과 조리면의 색도 측정은 color meter (CM-3600d, Minolta, Tokyo, Japan)를 사용하여 측정하였으 며, Hunter 값 즉, L(lightness), a(redness), b(yellowness)로 나타내었다. 이때 사용한 표준 백색판(standard plate)은 기 기의 사용법에 따라 값을 3 회 반복 측정하였으며 평균값으 로 나타내었다.

\section{국수의 조직감}

참취 국수 생면의 조직감 측정은 rheometer(COMPAC100 II, Compac, Tokyo, Japan)를 사용하여 측정하였다. 측 정조건에서 test type은 mastication test, distance $5 \mathrm{~mm}$, plunger diameter $15 \mathrm{~mm}$, adaptor type circle, table speed $60 \mathrm{~mm} / \mathrm{s}$, load cell(max) $2 \mathrm{~kg}$ 의 조건으로 5 회 반복 측정하였 다. 참취 국수의 생면은 면대를 형성한 후 일정한 크기 3 $\mathrm{cm} \times 3 \mathrm{~cm} \times 0.2 \mathrm{~cm}$ 로 하여 시료 중심부에 2 회 연속 압착하 였을 때 얻어지는 값을 산출하여 탄력성, 응집성, 씹힘성을 측정하였다.

\section{국수의 관능검사}

참취 국수의 조리면에 대한 관능검사는 Park 등(20)의 방법을 응용하였으며, 식품영양학 전공 대학원생 및 대학 생 20명을 관능검사원으로 선정하여 관능검사를 실시하기 전 각각의 항목에 대해 잘 인지하도록 충분히 설명하고 훈련한 후 관능검사를 실시하였다. 관능검사에 앞서 조리 면은 먼저 동일한 조건의 국물에 끓인 후 각 시료마다 무작
위로 조합된 3자리 숫자가 주어졌으며, 시료 번호가 쓰인 종이컵에 담아 제시하였다. 검사 방법은 7점 척도법을 사용 하고 각 평가 항목별(1점 매우 나쁘다, 2점 조금 나쁘다, 3점 나쁘다, 4점 보통, 5점 좋다 6점 조금 좋다, 7점 매우 좋다)로 평가되었다. 평가항목은 외관, 색, 향, 맛, 전체적 기호도로 나누어 실시하였다.

\section{통계처리}

$\operatorname{Park}(21)$ 의 방법을 응용하여 모든 실험은 3 회 이상 반복 실시하였고, 평균 \pm 표준편차로 표시하였다. 각 실험결과는 SPSS 통계프로그램(18.0, SPSS Inc, Chicago, IL, USA)을 이용하여 일원배치 분산분석 one-way ANOVA와 Duncan's multiple range test 실시하여 $\mathrm{p}<0.05$ 에서 유의성을 검증하 고, 분석하였다.

\section{결과 및 고찰}

\section{국수의 조리 특성}

참취 착즙액과 분말첨가 국수의 조리 시 변화를 측정한 조리특성은 Table 2에 나타내었다. 조리 후 중량은 대조군 과 참취 분말첨가 조리면이 참취 착즙액 첨가 조리면보다 유의적으로 낮았으며, 부피는 대조군에서 가장 높았고, 참 취 착즙액과 분말첨가 국수에서 낮았다.

수분 흡수율은 대조군에서 가장 높았으며, 참취 착즙액 과 분말첨가량이 많을수록 낮았다. 이러한 결과는 참취 분 말을 첨가한 국수의 연구에서 국수를 삶아 조리할 때 수분 의 흡수 정도에 따라 국수의 질감이 결정되는데 참취 착즙 액과 분말첨가량이 많을수록 수분의 흡수율이 낮아 국수의 탄력성을 높여 국수의 질감에 영향을 주게 되며 특히, 국수 의 품질특성에 크게 영향을 줄 수 있는 것으로 생각된다. $\operatorname{Min}$ 등(22)은 재료의 지방 및 섬유소 등의 성분이 밀가루의

Table 2. Properties of the cooked noodles added Aster scaber extract solution and powder

\begin{tabular}{ccccc}
\hline Sample ${ }^{1)}$ & $\begin{array}{c}\text { Weight after } \\
\text { cooking } \\
(\mathrm{g})\end{array}$ & $\begin{array}{c}\text { Volume after } \\
\text { cooking } \\
(\mathrm{mL})\end{array}$ & $\begin{array}{c}\text { Water } \\
\text { absorption rate } \\
(\%)\end{array}$ & $\begin{array}{c}\text { Turbidity of } \\
\text { soup } \\
(\text { OD at } 675 \mathrm{~nm})\end{array}$ \\
\hline Control & $18.90 \pm 0.04^{2)(3)}$ & $56.50 \pm 1.34^{\mathrm{a}}$ & $111.87 \pm 0.03^{\mathrm{a}}$ & $1.42 \pm 0.05^{\mathrm{a}}$ \\
AJ1 & $26.85 \pm 0.33^{\mathrm{a}}$ & $50.00 \pm 0.00^{\mathrm{b}}$ & $89.64 \pm 1.12^{\mathrm{b}}$ & $1.29 \pm 0.04^{\mathrm{b}}$ \\
AJ2 & $20.13 \pm 0.99^{\mathrm{b}}$ & $43.00 \pm 0.89^{\mathrm{c}}$ & $67.70 \pm 1.37^{\mathrm{d}}$ & $1.43 \pm 0.05^{\mathrm{a}}$ \\
AP1 & $18.04 \pm 0.14^{\mathrm{c}}$ & $44.00 \pm 0.89^{\mathrm{c}}$ & $72.47 \pm 1.10^{\mathrm{c}}$ & $1.12 \pm 0.02^{\mathrm{c}}$ \\
AP2 & $18.08 \pm 0.28^{\mathrm{c}}$ & $44.50 \pm 0.45^{\mathrm{c}}$ & $60.05 \pm 0.43^{\mathrm{e}}$ & $1.11 \pm 0.00^{\mathrm{c}}$ \\
\hline
\end{tabular}

${ }^{1)}$ Control, noodles not added Aster scaber extract solution and powder; AJ1, noodles added Aster scaber extract solution and water (1:4); AJ2, noodles added Aster scaber extract solution and water (1:2); AP1, noodles added Aster scaber powder of 1\%; AP2, noodles added Aster scaber powder of $3 \%$.

${ }^{2)}$ All values are expressed as mean \pm SD of triplicate determinations.

${ }^{3)}$ Different letters indicate significantly different at $\mathrm{p}<0.05$ by Duncan's multiple range test. 
수화력을 저하하기 때문에 조리 후 면의 중량, 부피 및 수분 흡수율은 감소하는 것으로 보고하였다. 반면, Lim 등(23)과 Park 등(24)의 경우 첨가량이 증가할수록 중량, 부피 및 수분흡수율은 증가하는 것으로 보고되었다. 따라서 면의 조리 후 중량, 부피 및 수분흡수율은 밀가루 전분의 수분흡 수력과 연관이 있으며, 면 제조 시 첨가되는 부재료의 종류 와 형태에 따라 면의 품질특성은 상이한 것으로 판단된다.

참취 착즙액과 분말첨가 국수를 끓인 국물의 탁도는 생 면의 조리 중 손실정도를 나타내는 척도로 대조군에 비해 참취 착즙액과 분말을 첨가한 국수 군에서 대체적으로 낮게 나타났다. 특히 $\mathrm{AJ} 2$ 에서 탁도가 대조군보다 높게 나타나 $\mathrm{AJ} 1$ 이상 국수에 첨가하였을 때 국수 품질에 나쁜 영향을 주는 것으로 생각되며, 참취 분말첨가농도는 탁도에 크게 영향을 주지 못한 결과를 보였다. 이와 같은 결과는 $\operatorname{Kim}(25)$ 과 $\operatorname{Kim}(26)$, Yang 등(27)의 연구에서도 첨가 농도가 높아짐 에 따라 탁도가 높은 것은 일반적으로 국수 제조 시 첨가물 의 양이 많아질수록 고형분의 손실량이 커져 탁도가 높아진 결과와 같이 본 연구에서도 참취 착즙액과 분말 첨가 농도 가 높을수록 탁도가 높았다.

\section{국수의 수분 함량 및 $\mathrm{pH}$}

참취 착즙액과 분말첨가 국수 생면의 수분함량 및 $\mathrm{pH}$ 를 측정한 결과는 Table 3 과 같다. 수분함량은 대조군이 $34.32 \%$ 의 함량을 보였고, 참취 착즙액을 첨가한 $\mathrm{AJ} 1$ 과 $\mathrm{AJ} 2$ 가 각각 $33.35,33.61 \%$ 의 함량을 보여 참취 즙액의 함량이 많은 $\mathrm{AJ} 2$ 가 $\mathrm{AJ} 1$ 에 비해 수분함량이 다소 높았다. 참취 분말 첨가 국수에서는 $\mathrm{AP} 1$ 과 $\mathrm{AP} 2$ 가 각각 $34.40,35.88 \%$ 의 수분 함량을 보여 참취 분말 첨가량이 많은 $\mathrm{AP} 2$ 가 $\mathrm{AP} 1$ 에 비해 수분함량이 다소 높았다.

참취 착즙액과 분말첨가 국수 생면의 $\mathrm{pH}$ 측정 결과, 대조 군에서는 $\mathrm{pH}$ 가 5.92, 참취 분말을 첨가한 국수 $\mathrm{AP} 1$ 과 $\mathrm{AP2}$ 에서 $\mathrm{pH}$ 가 각각 $5.89,5.84$, 참취 착즙액을 첨가한 국수는

Table 3. Moisture contents and $\mathrm{pH}$ of raw noodles added Aster scaber extract solution and powder

\begin{tabular}{ccc}
\hline Sample $^{1)}$ & Moisture contents (\%) & $\mathrm{pH}$ \\
\hline Control & $34.32 \pm 0.41^{2 \mathrm{bb})}$ & $5.92 \pm 0.02^{\mathrm{a}}$ \\
AJ1 & $33.35 \pm 0.05^{\mathrm{c}}$ & $4.62 \pm 0.01^{\mathrm{e}}$ \\
AJ2 & $33.61 \pm 0.13^{\mathrm{c}}$ & $4.73 \pm 0.01^{\mathrm{d}}$ \\
AP1 & $34.40 \pm 0.06^{\mathrm{b}}$ & $5.89 \pm 0.01^{\mathrm{b}}$ \\
AP2 & $35.88 \pm 0.56^{\mathrm{a}}$ & $5.84 \pm 0.00^{\mathrm{c}}$ \\
\hline F-value & $29.336^{* * *}$ & $8263.812^{* * *}$ \\
\hline
\end{tabular}

${ }^{1)}$ Control, noodles not added Aster scaber extract solution and powder; AJl, noodles added Aster scaber extract solution and water (1:4); AJ2, noodles added Aster scaber extract solution and water (1:2); AP1, noodles added Aster scaber powder of $1 \%$; AP2, noodles added Aster scaber powder of $3 \%$.

${ }^{2)}$ All values are expressed as mean $\pm \mathrm{SD}$ of triplicate determinations.

${ }^{3}$ Different letters indicate significantly different at $\mathrm{p}<0.05$ by Duncan's multiple range test.
$\mathrm{AJ} 1$ 과 $\mathrm{AJ} 2$ 에서 $\mathrm{pH}$ 가 각각 4.62, 4.73이었다. 대조군과 참취 분말을 첨가한 군에서는 참취 착즙액을 첨가한 국수군보다 다소 높은 $\mathrm{pH}$ 를 보였는데, 대조군과 참취 분말첨가군의 $\mathrm{pH}$ 는 약 5.8이상이었으며, 참취 착즙액을 첨가한 국수군은 $\mathrm{pH} 4.6$ 정도로 다소 낮은 $\mathrm{pH}$ 를 보였다.

버찌분말 첨가 국수(28)의 경우 버찌분말 첨가군은 초기 $\mathrm{pH}$ 는 5.46으로 나타났으며, 천년초 분말(29) 첨가군은 $\mathrm{pH}$ 가 5정도로 보고 하여 본 연구 결과와 유사하였다.

\section{국수의 색도}

참취 착즙액과 분말첨가 국수의 생면과 조리면의 색도를 나타낸 결과는 Table 4와 같다. 명도는 생면에서 대조군 87.90, AJ1 67.30, AJ2 65.53, AP1 68.45, AP2 65.24로 참취 착즙액과 분말첨가 국수군에 비해 대조군에서 명도는 높았 으며, 참취 착즙액과 분말첨가량이 증가할수록 명도는 낮 아졌다. 조리면에서는 대조군 71.87, $\mathrm{AJ} 1$ 55.01, AJ2 46.58, $\mathrm{AP} 1$ 56.40, AP2 47.01로 참취 착즙액과 분말첨가 국수군에 비해 대조군에서 명도는 높았으며, 참취 착즙액과 분말첨 가량이 증가할수록 명도는 낮아졌다.

적색도는 생면에서 대조군 - $1.09, \mathrm{AJ} 1-5.17, \mathrm{AJ} 2$-3.24, $\mathrm{AP} 1$-2.56, $\mathrm{AP} 2$-1.91로 참취 착즙액과 분말첨가 국수군에 비해 대조군에서 다소 높았으며, 참취 착즙액과 분말첨가 량이 증가할수록 높았다. 조리면에서의 적색도는 대조군 -2.84, $\mathrm{AJ} 1$-4.06, $\mathrm{AJ} 2$-3.88, $\mathrm{AP} 1$-3.20, $\mathrm{AP} 2$-2.54로 참취 착즙액과 분말첨가 국수군에 비해 대조군에서 높았으며, 참취 착즙액과 분말첨가량이 증가할수록 적색도는 높아졌 다. 또한, 생면과 조리면의 경우 참취 분말첨가 국수가 참취 착즙액첨가 국수에 비해 적색도는 대체적으로 높았다.

황색도는 생면에서 대조군 $11.17, \mathrm{AJ} 122.60, \mathrm{AJ} 2$ 13.29, $\mathrm{AP} 1$ 13.49, AP2 8.65로 참취 착즙액을 첨가한 국수가 대조 군과 분말첨가 국수군에 비해 높았으며, 참취 착즙액과 분 말첨가량이 증가할수록 낮아졌다. 조리면에서는 대조군 8.26, $\mathrm{AJ} 1$ 19.08, AJ2 18.04, $\mathrm{AP} 1$ 11.29, AP2 11.52로 참취 착즙액과 분말첨가 국수군에 비해 대조군에서 황색도는 낮았으며, 참취 착즙액첨가 국수군이 대조군과 참취 분말 첨가 국수군에 비해 황색도는 높았다.

참취 착즙액과 분말첨가량이 증가할수록 생면과 조리면 의 명도, 적색도, 황색도는 대체적으로 낮았고, 생면보다 조리면의 명도, 적색도, 황색도는 낮았다. 이는 $\mathrm{Kim}$ 등(30) 의 메수수가루 첨가한 생면과 조리면의 색도변화 결과와도 일치하였는데 이는 조리 중 적색소의 용출 및 면의 수분 흡수로 인하여 감소한 것으로 생각된다.

\section{국수의 기계적인 물성}

참취 착즙액과 분말을 첨가한 참취 국수 생면의 물성에 
Table 4. Hunter's color value of raw and cooked noodles added Aster scaber extract solution and powder

\begin{tabular}{ccccccc}
\hline \multirow{2}{*}{ Samples } & \multicolumn{2}{c}{$\mathrm{L}$} & \multicolumn{3}{c}{$\mathrm{a}$} & \multicolumn{2}{c}{$\mathrm{b}$} \\
\cline { 2 - 7 } & \multicolumn{1}{c}{$\mathrm{RN}^{2}$} & $\mathrm{CN}$ & $\mathrm{RN}$ & $\mathrm{CN}$ & $\mathrm{RN}$ & $\mathrm{CN}$ \\
\hline Control & $87.90 \pm 0.41^{3) \mathrm{a} 4)}$ & $71.87 \pm 0.37^{\mathrm{a}}$ & $-1.09 \pm 0.09^{\mathrm{a}}$ & $-2.84 \pm 0.09^{\mathrm{a}}$ & $11.17 \pm 0.40^{\mathrm{c}}$ & $8.26 \pm 0.33^{\mathrm{c}}$ \\
AJ1 & $67.30 \pm 1.22^{\mathrm{b}}$ & $55.01 \pm 0.60^{\mathrm{c}}$ & $-5.17 \pm 0.25^{\mathrm{e}}$ & $-4.06 \pm 0.27^{\mathrm{c}}$ & $22.60 \pm 0.48^{\mathrm{a}}$ & $19.08 \pm 0.67^{\mathrm{a}}$ \\
AJ2 & $65.53 \pm 1.15^{\mathrm{c}}$ & $46.58 \pm 0.25^{\mathrm{d}}$ & $-3.24 \pm 0.43^{\mathrm{d}}$ & $-3.88 \pm 0.06^{\mathrm{c}}$ & $13.29 \pm 0.77^{\mathrm{b}}$ & $18.04 \pm 0.83^{\mathrm{a}}$ \\
AP1 & $68.45 \pm 0.96^{\mathrm{b}}$ & $56.40 \pm 1.01^{\mathrm{b}}$ & $-2.56 \pm 0.14^{\mathrm{c}}$ & $-3.20 \pm 0.11^{\mathrm{b}}$ & $13.49 \pm 0.81^{\mathrm{b}}$ & $11.29 \pm 0.32^{\mathrm{b}}$ \\
AP2 & $65.24 \pm 0.55^{\mathrm{c}}$ & $47.01 \pm 0.39^{\mathrm{d}}$ & $-1.91 \pm 0.29^{\mathrm{b}}$ & $-2.54 \pm 0.14^{\mathrm{a}}$ & $8.63 \pm 0.86^{\mathrm{d}}$ & $11.52 \pm 0.68^{\mathrm{b}}$ \\
\hline F-value & $327.701^{* * *}$ & $727.735^{* * *}$ & $101.123^{* * *}$ & $43.871^{* * *}$ & $175.23^{* * *}$ & $145.359^{* * *}$ \\
\hline
\end{tabular}

${ }^{1)}$ Control, noodles not added Aster scaber extract solution and powder; AJl, noodles added Aster scaber extract solution and water (1:4); AJ2, noodles added Aster scaber extract solution and water (1:2); AP1, noodles added Aster scaber powder of 1\%; AP2, noodles added Aster scaber powder of 3\%.

${ }^{2)} \mathrm{RN}$, Raw Noodle; CN, Cooked Noodle.

${ }^{3)}$ All values are expressed as mean \pm SD of triplicate determinations.

${ }^{4}$ Different letters indicate significantly different at $\mathrm{p}<0.05$ by Duncan's multiple range test.

대한 측정 결과는 Table 5와 같다. 참취 착즙액과 분말을 첨가한 참취 국수의 탄력성(springness)은 대조군 130.74 $\mathrm{g}$, 참취 착즙액을 첨가한 국수 $\mathrm{AJ} 1, \mathrm{AJ} 2$ 는 각각 131.08 , $114.36 \mathrm{~g}$, 참취 분말을 첨가한 국수 $\mathrm{AP} 1, \mathrm{AP} 2$ 는 각각 131.07 , $112.28 \mathrm{~g}$ 으로 참취 착즙액과 분말의 첨가량이 증가할수록 탄력성은 감소하였다.

참취 착즙액과 분말을 첨가한 참취 국수의 응집성 (cohesiveness)은 대조군이 $651.66 \mathrm{~g}$, 참취 착즙액을 첨가한 국수 $\mathrm{AJ} 1, \mathrm{AJ} 2$ 는 각각 $395.20,492.31 \mathrm{~g}$, 참취 분말을 첨가한 국수 $\mathrm{AP1}, \mathrm{AP2}$ 는 각각 $341.69,381.02 \mathrm{~g}$ 로 대조군에서 응집 성이 가장 높았고, 참취 착즙액과 분말의 첨가량이 증가할 수록 응집성은 증가하였다. 또한, 참취 분말을 첨가한 국수 보다 참취 착즙액을 첨가한 국수의 응집성은 증가하였다.

참취 착즙액과 분말을 첨가한 참취 국수의 씹힘성 (chewiness)은 대조군의 씹힘성이 $454.29 \mathrm{~g}$, 참취 착즙액을 첨가한 국수 $\mathrm{AJ} 1, \mathrm{AJ} 2$ 는 각각 $345.92,387.56 \mathrm{~g}$, 참취 분말을 첨가한 국수 $\mathrm{AP} 1, \mathrm{AP} 2$ 는 각각 $405.07,422.68 \mathrm{~g}$ 로 대조군에 비해 참취 착즙액과 분말을 첨가한 국수의 씹힘성은 낮았 고, 참취 착즙액과 분말의 첨가량이 많을수록 씹힘성은 증 가함을 보였으며, 참취 착즙액을 첨가한 국수가 참취 분말 을 첨가한 국수군보다 씹힘성은 낮았다.

동결건조 마늘 분말(31)과 파프리카(32) 및 느타리버섯 (33)의 첨가량이 증가할수록 응집성, 탄력성이 감소한 연구 결과는 본 연구결과와 유사하였으나, 표고버섯(34), 머위분 말(35)을 첨가한 경우에는 증가하였다고 보고하였는데 이 는 국수 제조 시 첨가물의 종류나 비율에 따라 국수의 조직 감에 차이가 있음을 짐작 할 수 있다.

\section{국수의 관능검사}

참취 착즙액과 분말을 첨가하여 제조한 국수의 조리면에 대한 관능검사를 실시한 결과는 Table 6 과 같다. 참취 착즙 액과 분말첨가 국수의 관능검사는 외관, 색, 향, 맛, 전체적 인 기호도로 평가하였으며 7점법을 사용하였다.
참취 착즙액과 분말첨가 국수의 외관은 대조군에 비해 참취 착즙액과 분말을 첨가하여 제조한 국수군에서 높았 고, 특히 참취 착즙액의 농도가 높은 $\mathrm{AJ} 2$ 국수군에서 5.33으 로 높았으나 유의적 차이는 없었다. 색은 참취 착즙액을 첨가한 군 $\mathrm{AJ} 1, \mathrm{AJ} 2$ 에서 각각 5.00, 5.42로 분말을 첨가한 군 $\mathrm{AP} 1, \mathrm{AP2}$ 각각 $3.75,4.83$ 보다 기호도가 높았으며, $\mathrm{AJ} 2$ 의 색의 기호도가 높았다. 향은 대조군에서 4.58 , 참취 착즙액 을 첨가한 $\mathrm{AJ} 1, \mathrm{AJ} 2$ 각각 $4.67,4.58$ 과 분말을 첨가한 군 $\mathrm{AP} 1, \mathrm{AP2}$ 각각 $4.00,3.92$ 으로 분말보다는 착즙액을 첨가한 국수에서 높은 점수를 얻었으나 유의적 차이는 없었다.

맛은 대조군에서 3.75 , 참취 착즙액을 첨가한 $\mathrm{AJ} 1, \mathrm{AJ} 2$ 각각 $4.92,5.08$ 과 분말을 첨가한 국수군 $\mathrm{AP} 1, \mathrm{AP} 2$ 각각 $4.08,4.25$ 로 참취 착즙액 첨가군이 참취 분말을 첨가한 군보다 유의적으로 높은 점수를 보였다 $(\mathrm{p}<0.05)$. 전체적인 기호도는 대조군 4.00 에 비해 참취 착즙액 첨가 국수 $\mathrm{AJ} 1$, $\mathrm{AJ} 2$ 가 각각 $5.00,5.17$ 과 분말을 첨가한 국수군 $\mathrm{AP} 1, \mathrm{AP} 2$ 에 서 각각 $4.50,4.92$ 으로 참취 착즙액을 첨가한 국수군에서

Table 5. Textural properties of raw noodles added Aster scaber extract solution and powder

\begin{tabular}{cccc}
\hline Samples $^{1)}$ & $\begin{array}{c}\text { Springiness } \\
(\mathrm{g})\end{array}$ & $\begin{array}{c}\text { Cohesiveness } \\
(\mathrm{g})\end{array}$ & $\begin{array}{c}\text { Chewiness } \\
(\mathrm{g})\end{array}$ \\
\hline Control & $130.74 \pm 1.53^{2) \mathrm{a} 3)}$ & $651.66 \pm 1.32^{\mathrm{a}}$ & $454.29 \pm 1.43^{\mathrm{a}}$ \\
AJ1 & $131.08 \pm 0.65^{\mathrm{a}}$ & $395.20 \pm 2.93^{\mathrm{c}}$ & $345.92 \pm 1.61^{\mathrm{e}}$ \\
AJ2 & $114.36 \pm 3.02^{\mathrm{b}}$ & $492.31 \pm 2.09^{\mathrm{b}}$ & $387.56 \pm 1.09^{\mathrm{d}}$ \\
AP1 & $131.07 \pm 1.07^{\mathrm{a}}$ & $341.69 \pm 0.11^{\mathrm{e}}$ & $405.07 \pm 0.11^{\mathrm{c}}$ \\
AP2 & $112.28 \pm 6.42^{\mathrm{b}}$ & $381.02 \pm 1.46^{\mathrm{d}}$ & $422.68 \pm 1.22^{\mathrm{b}}$ \\
\hline F-value & $25.915^{* * *}$ & $13713.169^{* * *}$ & $3339.859^{* * *}$ \\
\hline
\end{tabular}

${ }^{1)}$ Control, noodles not added Aster scaber extract solution and powder; AJ1, noodles added Aster scaber extract solution and water (1:4); AJ2, noodles added Aster scaber extract solution and water (1:2); AP1, noodles added Aster scaber powder of 1\%; AP2, noodles added Aster scaber powder of $3 \%$.

${ }^{2)}$ All values are expressed as mean \pm SD of triplicate determinations.

${ }^{3)}$ Different letters indicate significantly different at $\mathrm{p}<0.05$ by Duncan's multiple range test. 
기호도가 높았으며, 참취 착즙액의 농도가 높은 $\mathrm{AJ} 2$ 참취 국수에서 높은 점수를 보였으나 유의적 차이는 없었다.

이러한 결과로 볼 때 전반적으로 대조군에 비해 참취 착즙액과 분말 첨가 국수의 선호도가 비교적 높게 나타남을 알 수 있었으며, 참취 착즙액과 분말의 첨가량이 많을수록 기호도는 증가하였고, 참취 착즙액의 첨가가 분말의 첨가 국수보다 선호도가 더 높았다.

Lee 등(36)은 머위 분말 첨가 시 명도가 낮아짐에도 불구 하고 기호도 측면에서 머위 분말을 첨가하지 않은 대조군보 다 높게 평가 되었다는 것은, 다양한 기능성 원료를 사용하 여 제조된 유색면에 대한 접촉기회가 많아져 유색면에 대한 거부감이 줄어들었으며 기호도도 높아지고 있어 기존의 흰색면에 한정 되지 않고 있음을 보여 주고 있다는 결과와 본 연구결과가 일치한다.

최근 다양한 원료를 사용하여 다양한 색상과 기능성을 살린 식품들이 많이 개발 시판되고 있는 현실을 감안하면 일반국수의 기능성과 기호도를 증가시킬 수 있는 참취 착즙 액과 참취 분말을 첨가한 국수는 충분한 연구가치가 있는 것으로 판단된다.

Table 6. Sensory characteristics of cooked noodles added Aster scaber extract solution and powder

\begin{tabular}{cccccc}
\hline Sample $^{1)}$ & Apperance & Color & Smell & Taste & $\begin{array}{c}\text { Overall } \\
\text { acceptability }\end{array}$ \\
\hline Control & $4.42 \pm 1.50^{2) \mathrm{a} 3)}$ & $4.58 \pm 1.37^{\mathrm{a}}$ & $3.83 \pm 1.03^{\mathrm{a}}$ & $3.75 \pm 1.28^{\mathrm{b}}$ & $4.00 \pm 1.53^{\mathrm{a}}$ \\
AJ1 & $4.75 \pm 0.87^{\mathrm{a}}$ & $5.00 \pm 0.95^{\mathrm{a}}$ & $4.67 \pm 1.07^{\mathrm{a}}$ & $4.92 \pm 0.90^{\mathrm{a}}$ & $5.00 \pm 1.04^{\mathrm{a}}$ \\
AJ2 & $5.33 \pm 0.98^{\mathrm{a}}$ & $5.42 \pm 1.31^{\mathrm{a}}$ & $4.58 \pm 1.31^{\mathrm{a}}$ & $5.08 \pm 1.08^{\mathrm{a}}$ & $5.17 \pm 1.69^{\mathrm{a}}$ \\
AP1 & $4.50 \pm 0.67^{\mathrm{a}}$ & $3.75 \pm 0.62^{\mathrm{a}}$ & $4.00 \pm 1.41^{\mathrm{a}}$ & $4.08 \pm 0.99^{\mathrm{ab}}$ & $4.50 \pm 0.90^{\mathrm{a}}$ \\
AP2 & $4.75 \pm 0.87^{\mathrm{a}}$ & $4.83 \pm 1.02^{\mathrm{a}}$ & $3.92 \pm 1.51^{\mathrm{a}}$ & $4.25 \pm 1.42^{\mathrm{ab}}$ & $4.92 \pm 1.50^{\mathrm{a}}$ \\
\hline
\end{tabular}

${ }^{1)}$ Control, noodles not added Aster scaber extract solution and powder; AJ1, noodles added Aster scaber extract solution and water (1:4); AJ2, noodles added Aster scaber extract solution and water (1:2); AP1, noodles added Aster scaber powder of 1\%; AP2, noodles added Aster scaber powder of $3 \%$.

${ }^{2)}$ Values are mean \pm SD $(n=20)$.

${ }^{3)}$ Different letters indicate significantly different at $\mathrm{p}<0.05$ by Duncan's multiple range test.

\section{요 약}

본 연구는 참취를 이용한 가공식품의 개발을 위하여 참 취 착즙액 및 참취 분말을 첨가한 참취 국수의 개발과 더불 어 이들 첨가량에 따른 수분함량, 재흡수률, 색도, 물성 등 이화학적 특성과 조리국수의 관능적 특성을 조사하였다. 참취 국수의 품질특성 결과, 참취 국수의 조리 후 중량은 대조군과 착즙액을 첨가한 국수에서 높았고, 수분흡수율은 참취 첨가량이 많을수록 낮게 나타났다. 참취 국수의 생면 과 조리면의 색도 측정 결과 $\mathrm{L}$ 값은 참취 첨가량이 증가할수 록 감소했고, $\mathrm{a}$ 값은 모두 음의 값을, $\mathrm{b}$ 값은 모두 양의 값을 보여 녹황색임을 의미하였다. 참취 국수 생면의 $\mathrm{pH}$ 는 대조
군 및 분말 첨가 국수에서 $\mathrm{pH}$ 5 6을 보였으며, 착즙액을 첨가한 국수에서는 보다 낮은 $\mathrm{pH}$ 값을 보였다. 참취 국수 생면의 물성 측정 결과 탄력성은 참취의 첨가량이 적을수록 높았고, 응집성은 대조군에서 가장 높았으며, 씹힘성은 참 취 분말을 첨가한 국수에서 높았다. 참취 국수 조리면의 관능 평가는 대조군에 비해 참취 착즙액과 분말첨가 국수의 기호도가 비교적 높았으며, 특히 참취 착즙액을 첨가한 국 수가 분말첨가 국수보다 기호도가 더 높았다. 따라서 참취 착즙액과 분말을 첨가한 참취 국수는 대조군에 비해 기호성 등이 우수하였으며, 참취를 이용한 다양한 가공식품의 개 발은 국민 건강과 더불어 참취의 소비확대 및 부가가치 창출에 이바지할 수 있을 것으로 기대된다.

\section{감사의 글}

연구는 지식경제부에서 시행한 지역산업기술개발사업 (과제번호 : 0000780)의 지원을 받아 수행된 연구의 일부이 며 이에 감사드립니다.

\section{References}

1. Kim J (2003) Enhancing effect of Paeonia japonica, Houttuynia cordata, and Aster scaber extracts on the immunore activity in vivo in mice. $\mathrm{Ph} \mathrm{D}$ Thesis, Sookmyung Women's University, Korea

2. Yun EK (2001) Studies on the physiological functionality of Chamchwi (Aster scaber Thunb.) extract. MS Thesis, Pusan National University, Korea

3. Hong JY, Kim KM, Nam HS, Shin SR (2014) Antioxidant activities of hot-water extracts from Aster scaber by cultivation and drying methods. Koeran J Food Preserv, $21,82-90$

4. Lee JS (2012) Quality characteristics of wet noodles added with freeze-dried purple sweet potato powder. Korean J Culinary Res, 18, 279-292

5. Bong JE (2009) Antioxidative activity of Heracleum moellend orffii $\mathrm{H}$. extract $\mathrm{s}$ and quality characteristics of Heracleum moellend orffii $\mathrm{H}$. raw noodle. MS Thesis, Sookmyung Women's University, Korea

6. Hong YM, Kim JS, Kim DW, Kim WJ (2003) Effect of whole soy flour on the properties of wet noodle. Korean J Food Nutr, 16, 417-422

7. Jeong CH, Shim KH, Bae YI, Choi JS (2008) Quality characteristics of wet noodle added with freeze dried garlic powder. J Korean Soc Food Sci Nutr, 37, 
1369-1374

8. Shin WS, Shin ES, Lyu ES (2009) Optimization of wet noodle with onion juice using response surface methodology. Korean J Food Cookery Sci, 25, 31-38

9. Kong S, Lee J (2010) Quality characteristics and changes in GABA content and antioxidant activity of noodle prepared with germinated brown rice. J Korean Soc Food Sci Nutr, 39, 274-280

10. Kim JS, Ahn JS, Ahn KY (2013) Quality characteristics of fresh noodles with hot-air-dried perilla leaf powder. Korean J Culinary Res, 19, 73-86

11. Lee JS, Yoo SS (2012) Quality characteristics of wet noodles added with purple sweet potato powder. J East Asian Soc Dietary Life, 22, 489-496

12. Han SM, Han JA (2011) Preparation and characterization of wet noodle containing germinated small black bean flour. Korean J Food Sci Technol, 43, 597-602

13. Ko HC, Kim JS (2011) Quality characteristics of fresh pasta noodles containing added citrus peel powder. J East Asian Soc Dietary Life, 21, 250-256

14. Hwang IG, Kim HY, Hwang Y, Jeong HS, Yoo SM (2011) Quality characteristics of wet noodles combined with cheongyang hot pepper (capsicum annuum L.) extract solution. J Korean Soc Food Sci Nutr, 40, 860-866

15. Kim KM (2004) A study of color image for food styling (focused on fresh noodle packaging). MS Thesis, Kyonggi University, Korea

16. Lee HA, Nam ES, Park SI (2003) Effect of maesil (Prunus mume) juice on antimicrobial activity and shelf-life of wet noodle. Korean J Food Culture, 18, 428-436

17. Han MW, Park KJ, Jeong SW, Kim SJ, Youn KS (2007) Effects of pediocin treatment on the microbial quality of wet noodles during storage. Korean J Food Preserv, 14, 328-331

18. Lee YS, Lim NY, Lee KH (2000) A study on the preparation and evaluation of dried noodle products made from composite flours utilizing arrowroot starch. Korean J Soc Food Sci, 16, 681-688

19. Park BH, Cho HS (2006) Quality characteristics of dried noodles made with Dioscorea japonica flour powder. Korean J Food Cookey Sci, 22, 173-180

20. Park BH, Joo HM, Cho HS (2014) Quality characteristics of dried noodles added with Ligularia fischeri powder. Korean J Food Culture, 29, 205-211

21. Park WP (2014) Quality characteristics of noodles added with Houttuynia cordata Thunb powder. Korean J Food Preserv, 21, 34-39
22. Min SH, Shin S, Won M (2010) Characteristics of noodles with added Polygonati odoratum powder. J East Asian Soc Dietary Life, 20, 524-530

23. Lim YS, Cha WJ, Lee SK, Kim YJ (2003) Quality characteristics of wet noodle with Lycii fructus power. Korean J Food Sci Technol, 35, 77-83

24. Park SI, Cho EJ (2004) Quality characteristics of noodle added with chlorella extract. Korean J Food Nutr, 17, 120-127

25. Kim YS (1998) Quality of wet noodle prepared with wheat flour and mushroom powder. Korean J Food Sci Technol, 30, 1373-1380

26. Kim SJ (2013) Preparation and characteristics of konjac noodle added mugwort. J East Asian Soc Dietary Life, 23, 613-619

27. Yang HC, Suk KS, Lim MH (1982) Studies on the processing of raw material for noodles. Korean $\mathrm{J}$ Food Technol, 14, 146-150

28. Kim SH, Jung BM (2013) Quality characteristics of noodles containing various levels of flowering cherry (Prunus serrulata L. var. spontanea Max. wils.) fruit powder. Korean J Food Cookery Sci, 29, 19-28

29. Jung BM (2010) Quality characteristics and storage properties of wet noodle with added cheonnyuncho fruit powder. Korean J Food Cookey Sci, 26, 821-830

30. Kim HY, Ko JY, Kim JI, Jung TW, Yun HT (2013) Quality and antioxidant activity of wet noodles supplemented with non-glutinous sorghum powder. Korean J Food Sci Technol, 45, 521-525

31. Lee HJ (2013) Study on rheological properties of wheat flour mixed with garlic powder. Korean J Food Nutr, 26, 345-351

32. Jeong $\mathrm{CH}$ and $\mathrm{Kim} \mathrm{JH}$, Cho JR, Ahn CG, Shim KH (2007) Quality characteristics of wet noodles added with Korean paprika powder. J Korean Soc Food Sci Nutr, 36, 779-784

33. Kim YS (1998) Quality of wet noodle prepared with wheat flour and mushroom powder. J Korean Soc Food Sci Nutr, 30, 1373-1380

34. Ko SH, Joo NM (2009) Optimization of pasta with the addition of Letinus edodes powder. J Korean Diet Assoc, 15,359

35. Lee KH, Kim KT (2000) Properties of wet noodle changed by the addition of whey powder. Korean J Food Sci Technol, 32, 1073-1078

36. Lee KH (2011) Antioxudative activity of butterbur extracts and quality characteristics of butterbur noodles. MS Thesis, Sookmyung Women's University, Korea 